Jurnal Media Pertanian Vol. 3 No. 1 Tahun 2018 Hal. 16 - 23

Media Komunikasi Hasil Penelitian dan Review Literatur Bidang Ilmu Agronomi

ISSN print $2503-1279$

ISSN online $2581-1606$

\title{
PENGENDALIAN KUTU DAUN PADA TANAMAN CABAI YANG DIAPLIKASI BIOCHAR DAN TRICHOKOMPOS BERDASARKAN AMBANG KENDALI
}

\author{
Araz Meilin \\ Prodi Agroteknologi, Fakultas Pertanian Universitas Batanghari \\ Jl. Slamet Riyadi, Broni Jambi, 36122. Telp. +6274160103 \\ Email : araz_meilin@yahoo.com
}

\begin{abstract}
The control of aphids pests in chilli plantation often uses scheduled chemical control. This study aims to determine the development of aphid populations in the vegetative phase of chili plants treated with biochar from agricultural waste and trichokompos, and its control based on the threshold of control. The experiment was conducted on chili varietas Kencana of vegetative phase in Sangir Tengah Village, Kayu Aro Subdistrict, Kerinci Regency in 2016. The planting of chili was carried out with five treatments: 1) Trichokompos 10 ton/ha and 2 ton/ha of bagasse biochar; 2) Trichokompos 10 ton $\mathrm{ha}^{-1}$ and 2 ton ha ${ }^{-1}$ of corncob biochar; 3) Trichokompos 10 ton $\mathrm{ha}^{-1}$ and 2 ton ha $\mathrm{h}^{-1}$ of rice husk biochar; 4) Trichokompos 10 ton $\mathrm{ha}^{-1}$; and 5) Control (farmer technology). Each treatment was repeated 4 times. The environmental design used is Randomized block design (RBD). Data collection through observation of population number of aphids done every week. Control measures with the use of pesticides are carried out after the population passes the economic threshold. The results showed that the use of agricultural waste biochar (rice husk, corncob, bagasse) and trichokompos did not significantly affect the number/population of aphids. Chemical control of aphids on chili plants in the vegetative phase based on the control threshold can reduce the frequency of insecticide application up to $50 \%$.
\end{abstract}

Keywords: control threshold, insecticide, chili pest

\begin{abstract}
Abstrak
Pengendalian hama kutu daun pada tanaman cabai sering menggunakan pengendalian kimia yang terjadwal. Penelitian ini bertujuan untuk mengetahui perkembangan populasi kutu daun pada fase vegetatif tanaman cabai yang diberi perlakuan biochar asal limbah pertanian dan trichokompos dan pengendaliannya berdasarkan ambang kendali. Penelitian dilaksanakan pada pertanaman cabai varietas Kencana fase vegetatif di Desa Sangir Tengah, Kecamatan Kayu Aro, Kabupaten Kerinci pada tahun 2016. Penanaman cabai dilaksanakan dengan lima perlakuan yaitu : 1) Trichokompos 10 ton $\mathrm{ha}^{-1}$ dan biochar ampas tebu 2 ton ha ${ }^{-1}$; 2) Trichokompos 10 ton $\mathrm{ha}^{-1}$ dan biochar tongkol jagung 2 ton $\mathrm{ha}^{-1}$; 3) Trichokompos 10 ton $\mathrm{ha}^{-1}$ dan biochart sekam padi 2 ton $\mathrm{ha}^{-1}$; 4) Trichokompos 10 ton $\mathrm{ha}^{-1}$; dan 5) Kontrol (teknologi petani). Masing-masing perlakuan diulang sebanyak 4 kali. Rancangan lingkungan yang digunakan adalah Rancangan Acak Kelompok (RAK). Pengumpulan data melalui pengamatan jumlah populasi kutu daun yang dilakukan setiap minggu. Tindakan pengendalian dengan penggunaan insektisida dilakukan setelah populasi melewati ambang ekonomi. Hasil penelitian
\end{abstract}

Diterbitkan oleh Program Studi Agroteknologi Fakultas Pertanian Universitas Batanghari Jambi Halaman 16 
Jurnal Media Pertanian Vol. 3 No. 1 Tahun 2018 Hal. 16 - 23

Media Komunikasi Hasil Penelitian dan Review Literatur Bidang Ilmu Agronomi ISSN print $2503-1279$

ISSN online $2581-1606$

menunjukkan bahwa penggunaan biochar limbah pertanian (sekam padi, tongkol jagung, ampas tebu) dan trichokompos tidak berpengaruh nyata terhadap jumlah/populasi kutu daun. Pengendalian kimia kutu daun pada tanaman cabai varietas Kencana pada fase vegetatif yang dilakukan berdasarkan ambang kendali, dapat menurunkan frekuensi aplikasi insektisida sampai 50\%.

Kata kunci : ambang kendali, insektisida, hama cabai

\section{PENDAHULUAN}

Cabai merupakan salah satu dari tujuh komoditas strategis nasional. Provinsi Jambi terutama Kabupaten Kerinci merupakan kawasan sentra produksi cabai. Dalam dua tahun terakhir, kontribusi luas panen dan produksi cabai di Kabupaten Kerinci mengalami peningkatan. Pada tahun 2014, luas panen cabai di Kabupaten Kerinci 3.554 ha lebih 50\% dari luas panen cabai di Provinsi Jambi (6.410 ha), dan produksi cabai di Kabupaten Kerinci 32.908 ton lebih dari 70\% produksi cabai di Provinsi Jambi (43.479 ton) (BPS, 2015).

Organisme pengganggu tumbuhan (OPT) masih menjadi salah satu kendala utama pada budidaya cabai. Tanaman cabai yang dibudidayakan pada dataran tinggi dapat diserang oleh beberapa hama dan penyakit yaitu : Thrips parvispinus, Aphis gossypii, Spodoptera litura, Polyphagotarsonemus latus, Cercospora sp. Oidiopsis sp. Heliothis armigera, Bactrocera sp. dan C. capsici (Prabaningrum \& Moekasan, 2014). Hama yang ditemukan pada lahan budidaya cabai secara vertikultur yaitu kutu daun aphid dan kutu kebul Bemisia tabacci. Penyakit yang ditemukan pada lahan budidaya cabai secara vertikultur yaitu penyakit yang disebabkan oleh virus gemini yang ditularkan oleh kutu kebul (Roziq et al. 2013). Sejak fase vegetatif hingga fase generatif, tanaman cabai merah selalu mendapat serangan OPT. Menurut Gunaeni \& Wulandari (2010), kehilangan hasil akibat serangan penyakit virus CMV berkisar antara 18,3 98,6\%. Serangan hama ulat buah Helicoverpa armigera mengakibatkan kehilangan hasil hingga 60\% (Setiawati et al. 2011), sementara penyakit antraknos dapat menyebabkan kerusakan buah hingga 0,3 - 44\% (Herwidyarti et al, 2013). Sejak awal 2003 terjadi epidemi serangan virus gemini pada pertanaman cabai merah di berbagai daerah di Indonesia, yang mengakibatkan panen cabai merah mengalami gagal panen, sehingga harga cabai merah melonjak, sementara petani merugi milyaran rupiah (Duriat 2008, Setiawati et al. 2007).

Budidaya cabai di Kabupaten Kerinci masih mengandalkan penggunaan pestisida kimia dalam pengendalian organisme pengganggu tanaman (OPT) dan pemupukan menggunakan pupuk kimia. Penggunaan pestisida dilakukan berjadwal (setiap minggu atau kurang dari seminggu) dengan frekuensi penggunaan pestisida sampai lebih 20 kali per musim tanam dan mencampur beberapa jenis pestisida bersamaan. Banyak jenis bahan aktif pestisida yang sudah digunakan oleh petani di Kabupaten Kerinci, diantaranya adalah Profenofos, Difenokonazol, Dimehipo, Sipermetrin, Azoxistrobin, difenokonazol, Tiametoksam Klorantraniliprol, Klorpirifos, Abamektin dan Propineb (Endrizal et al., 2014). Dampak negatif penggunaan pupuk kimia dan pestisida kimia atau anorganik secara terus menerus adalah terjadinya degradasi kesuburan tanah,

Diterbitkan oleh Program Studi Agroteknologi Fakultas Pertanian Universitas Batanghari Jambi Halaman 17 
Jurnal Media Pertanian Vol. 3 No. 1 Tahun 2018 Hal. 16 - 23

Media Komunikasi Hasil Penelitian dan Review Literatur Bidang Ilmu Agronomi ISSN print $2503-1279$ ISSN online $2581-1606$

rusaknya ekosistem pertanian, rusaknya ekosistem perairan, dan hasil panen yang masih mengandung sisa bahan aktif pestisida tersebut.. Biochar merupakan suatu alternatif yang digunakan sebagai bahan pembenah tanah yang tercemar pupuk dan pestisida anorganik serta dapat memperbaiki tanah yang telah mengalami degradasi. Biochar merupakan bahan berwarna hitam atau disebut juga arang hayati yang berasal dari pembakaran tidak sempurna (pirolisis) bahan organik sisa-sisa hasil pertanian, yang kaya karbon dan memiliki daya tahan tinggi terhadap dekomposisi dan mineralisasi karena karbon dalam biochar dalam bentuk senyawa aromatik (Schmidt et al., 2001).

Beberapa penelitian untuk mendapatkan komponen teknologi pengendalian OPT telah banyak dilakukan. Moekasan et al. (2004) melaporkan bahwa penerapan ambang pengendalian OPT pada budidaya cabai di dataran rendah dapat menekan penggunaan pestisida $>50 \%$. Fase vegetatif tanaman merupakan fase tanaman yang harus dijaga dari serangan OPT. Penelitian ini bertujuan untuk mengetahui perkembangan populasi kutu daun pada fase vegetatif tanaman cabai yang diberi perlakuan biochar asal limbah pertanian dan trichokompos, dan pengendaliannya berdasarkan ambang kendali.

\section{METODOLOGI PENELITIAN}

Penelitian dilaksanakan pada pertanaman cabai varietas Kencana di Desa Sangir Tengah, Kecamatan kayu Aro, Kabupaten Kerinci, Jambi. Pada bulan September-Desember 2016. Rancangan percobaan yang digunakan adalah budidaya cabai dengan perlakuan sebagai berikut :

1) Trichokompos 10 ton ha ${ }^{-1}$ dan biochar ampas tebu 2 ton ha-

2) Trichokompos 10 ton ha ${ }^{-1}$ dan biochar tongkol jagung 2 ton ha ${ }^{-1}$

3) Trichokompos 10 ton $\mathrm{ha}^{-1}$ dan biochart sekam padi 2 ton $\mathrm{ha}^{-1}$,

4) Trichokompos 10 ton ha ${ }^{-1}$

5) Kontrol (teknologi petani)

Masing-masing perlakuan diulang sebanyak 4 kali. Rancangan lingkungan yang digunakan adalah rancangan acak kelompok (RAK).

\section{Pelaksanaan}

Pengolahan tanah dilakukan menggunakan traktor mini dan cangkul sesuai dengan perlakuan. Setiap unit percobaan menggunakan 4 unit bedengan yang merupakan ulangan. Bedengan dibuat dengan ketinggian 20-30 cm, lebar $1 \mathrm{~m}$ dan panjang bedengan disesuaikan dengan kondisi lahan yang ada dan minimal 15 meter. Jarak antara bedengan adalah $60 \mathrm{~cm}$. Setiap bedengan ditutup dengan mulsa plastik setelah aplikasi semua perlakuan. Lubang tanam ditanam dibuat sebanyak dua baris dalam setiap bedengan. Lubang tanam dibuat zig zag, tidak sejajar, hal ini berguna untuk mengatur sirkulasi angin dan penetrasi sinar matahari. Diameter dan kedalaman lubang tanam kurang lebih $10 \mathrm{~cm}$. Lahan percobaan dikelilingi tanaman jagung minimal 2 baris dan Tagetes sp. sebagai border dengan jarak tanam rapat yang ditanam setelah pengolahan tanah.

Pupuk trichokompos diberikan pada setiap bedengan, diratakan, kemudian dilanjutkan dengan pemberian biochar sesuai perlakuan, pemberian pupuk NPK, dilanjutkan dengan penutupan tanah dengan mulsa plastik. Pada setiap lubang

Diterbitkan oleh Program Studi Agroteknologi Fakultas Pertanian Universitas Batanghari Jambi Halaman 18 
Jurnal Media Pertanian Vol. 3 No. 1 Tahun 2018 Hal. 16 - 23

Media Komunikasi Hasil Penelitian dan Review Literatur Bidang Ilmu Agronomi ISSN print $2503-1279$

ISSN online $2581-1606$

tanam ditanam satu bibit cabai yang sehat. Jarak tanam yang digunakan adalah 80 $\mathrm{cm}$ antar baris dan $50 \mathrm{~cm}$ antar bibit dalam satu bedengan.

Penyiraman diperlukan pada saat musim kering. Penyiraman dilakukan dengan hati-hati terutama pada disaat tanaman belum terlalu kuat. Pemeriksaan tanaman dilakukan 1 sampai 2 minggu pertama untuk melakukan penyulaman tanaman. Apabila ada tanaman yang mati atau pertumbuhannya abnormal segera dicabut dan ganti dengan bibit yang baru.

Pemasangan ajir (tongkat bambu) dilakukan untuk menopang tanaman berdiri tegak. Ajir ditancapkan dengan jarak minimal $4 \mathrm{~cm}$ dari pangkal batang. Pemasangan ajir dilakukan pada hari ke-7 sejak bibit dipindahkan, karena apabila tanaman terlalu besar dikhawatirkan saat ajir ditancapkan akan melukai perakaran. Bila akar terluka tanaman akan mudah terserang penyakit. Pengikatan tanaman pada ajir dilakukan setelah tanaman tumbuh tinggi atau berumur diatas satu bulan.

Perempelan atau pemotongan tunas dilakukan setelah 1 bulan dengan cara memotong tunas yang tumbuh pada ketiak daun dengan tangan yang bersih. Perempelan dilakukan sampai terbentuk cabang utama, ditandai dengan kemunculan bunga pertama atau kedua.

Pemupukan susulan dilakukan setiap dua minggu sekali. Pemupukan susulan dilakukan dengan pengocoran pupuk pada setiap lubang tanam. Pupuk yang digunakan adalah pupuk organik cair, sebanyak $100 \mathrm{ml}$ larutan pupuk yang telah diencerkan. Penyiangan gulma dilakukan apabila diperlukan saja.

Pengendalian organisme pengganggu tanaman (OPT) utama pada semua petak perlakuan dilakukan jika populasi atau intensitas serangan OPT telah mencapai ambang pengendalian, menurut Moekasan et al. (2004), Moekasan \& Prabaningrum (2012), untuk hama kutu daun, jika populasi telah mencapai 0,7 ekor per daun pucuk. Jika telah melewati ambang kendali, dilakukan penyemprotan dengan insektisida dengan bahan aktif Abamektin sesuai dosis yang direkomendasikan. Pengamatan dilakukan mulai tanaman berumur 7 hari dengan interval 7 hari. Sepuluh tanaman pada setiap petak perlakuan ditetapkan sebagai tanaman contoh secara acak sistematis. Peubah yang diamati pada tanaman contoh ialah :tinggi tanaman diukur dari permukaan tanah sampai pucuk tanaman cabai, populasi kutu daun, yaitu dengan cara menghitung jumlah individu kutu daun per daun contoh per tanaman contoh. Daun contoh tersebut letaknya lima helai dari daun daun pucuk. Data pengamatan dianalisis dengan sidik ragam menggunakan program SPSS dan dilanjutkan dengan uji Duncan untuk mengetahui pengaruh antar perlakuan.

\section{HASIL DAN PEMBAHASAN}

Penggunaan biochar limbah pertanian pada lahan cabai menunjukkan pengaruh yang nyata pada tinggi tanaman cabai yang diamati pada umur 3-7 MST (minggu setelah tanam). Pada 3 MST, tinggi tanaman cabai berbeda nyata dan lebih tinggi pada perlakuan biochar ampas tebu dibanding kontrol dan perlakuan lainnya. Selanjutnya sampai 7 MST, perlakuan dengan biochar ampas tebu dan sekam padi menunjukkan tinggi tanaman yang berbeda nyata dan lebih tinggi dibanding perlakuan lainnya termasuk kontrol (Gambar 1). Perlakuan kontrol yang tidak mendapatkan pupuk trichokompos maupun pupuk kimia tidak dapat

Diterbitkan oleh Program Studi Agroteknologi Fakultas Pertanian Universitas Batanghari Jambi Halaman 19 
Jurnal Media Pertanian Vol. 3 No. 1 Tahun 2018 Hal. 16 - 23

Media Komunikasi Hasil Penelitian dan Review Literatur Bidang Ilmu Agronomi ISSN print $2503-1279$

ISSN online $2581-1606$

memenuhi kebutuhan unsur hara untuk proses pertumbuhan tinggi tanaman. Apabila kebutuhan unsur hara tidak tercukupi oleh tanaman maka akan dapat mengakibatkan terganggunya proses pertumbuhan tanaman. Unsur hara sangat dibutukan oleh tanaman selama fase hidupnya Unsur hara akan dimanfaatkan tanaman untuk memacu proses fotosintesis (Gardner et al. 1991). Hasil dari fotosintesis akan ditranslokasikan ke seluruh bagian tanaman untuk memacu perkembangan vegetatif dan generatif tanaman. Menurut Novizan (2007), pemberian biochar mampu mengikatkan unsur N, Ca,dan K. Semua bahan organik yang ditambahkan ke dalam tanah nyata dapat meningkatkan ketersediaan berbagai unsur hara esensial bagi pertumbuhan tanaman. Namun, biochar lebih efektif menahan ketersediaan unsur hara bagi tanaman dibandingkan dengan bahan organik lain seperti sampah dedaunan, kompos atau pupuk kandang (Gani, 2009). Selain Itu, pemberian biochar pada budidaya tanaman juga dapat menghambat perkembangan hama (Hou, et al., 2015).

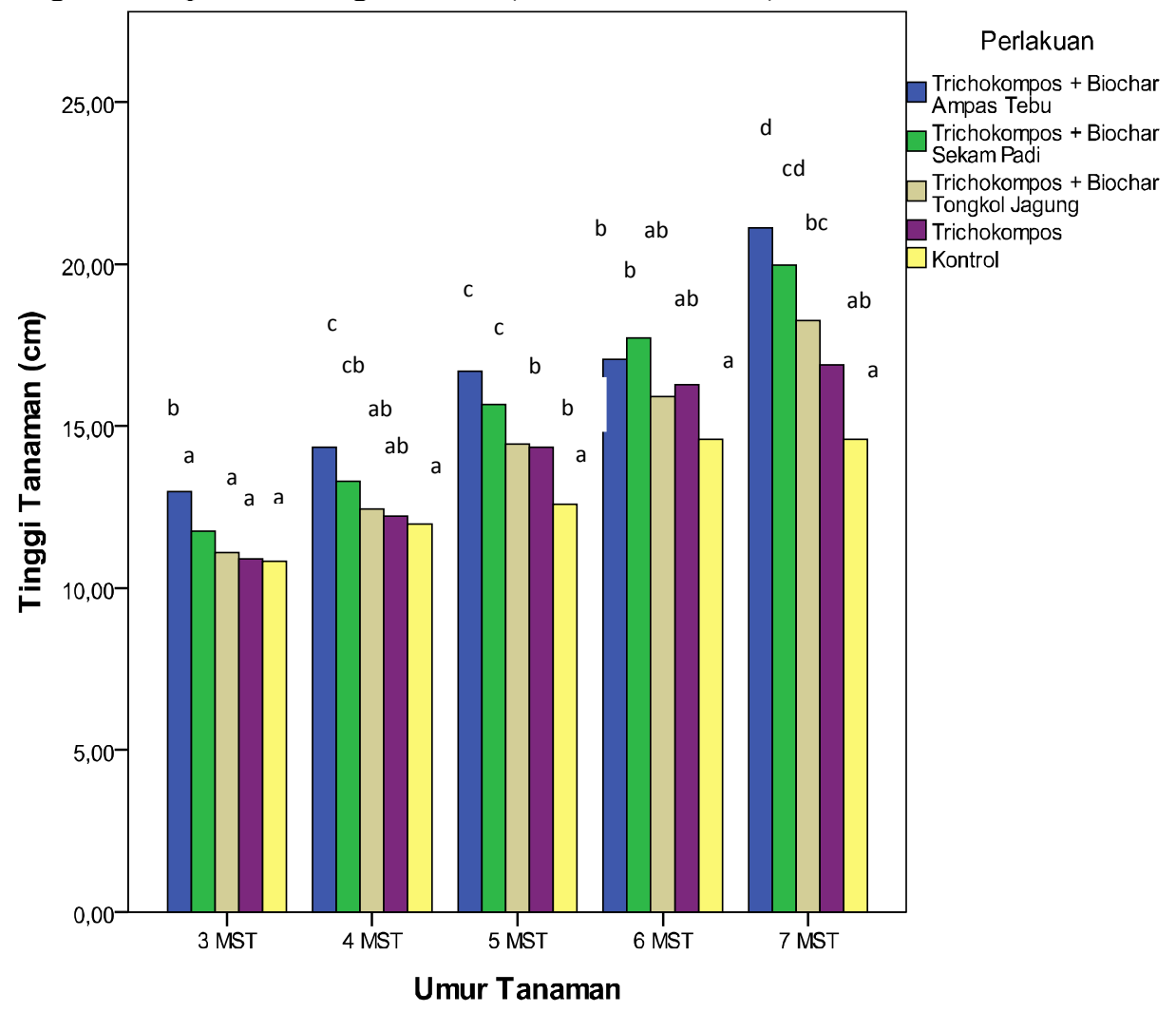

Gambar 1. Tinggi tanaman cabai 3-7 MST pada setiap perlakuan biochar

Hasil pengamatan menunjukkan bahwa jumlah kutu daun pada tanaman cabai dengan perlakuan beberapa jenis biochar ditambah trichokompos dan trichokompos saja tidak berpengaruh nyata dengan perlakuan tanpa pemberian biochar dan trichokompos (kontrol) pada 2-7 MST. Tabel 1 menunjukkan bahwa rata-rata populuasi kutu daun pada budidaya cabai tanpa pemberian biochar dan

Diterbitkan oleh Program Studi Agroteknologi Fakultas Pertanian Universitas Batanghari Jambi Halaman 20 
Jurnal Media Pertanian Vol. 3 No. 1 Tahun 2018 Hal. 16 - 23

Media Komunikasi Hasil Penelitian dan Review Literatur Bidang Ilmu Agronomi ISSN print $2503-1279$

ISSN online $2581-1606$

trichokompos (kontrol) lebih tinggi dibanding tanaman cabai dengan perlakuan biochar dan trichokompos, atau trichokompos saja.

Tabel 1. Perkembangan jumlah kutu daun pada tanaman cabai dengan beberapa perlakuan

biochar pada 2-7MST

\begin{tabular}{llccccc}
\hline No & Perlakuan & 2 & 3 & 4 & 5 & 7 \\
\cline { 3 - 6 }. & & \multicolumn{3}{c}{ MST (Minggu Setelah Tanam) } \\
\hline 1 & Biochar Sekam Padi + Trichokompos & 1,12 & 0,50 & 0,62 & 0,37 & 0,25 \\
2 & Biochar Tongkol Jagung + Trichokompos & 0,81 & 0,43 & 0,37 & 0,37 & 0,31 \\
3 & Biochar Ampas Tebu + Trichokompos & 1,30 & 1,06 & 0,31 & 0,31 & 0,62 \\
4 & Trichokompos & 0,75 & 1,00 & 0,43 & 0,37 & 0,31 \\
5 & Kontrol & 1,50 & 1,12 & 0,62 & 0,50 & 1,00 \\
\hline
\end{tabular}

Pada 2 MST, rata-rata populasi kutu daun diatas 0,7 ekor per daun pucuk pada semua perlakuan. Kondisi ini menunjukkan bahwa kutu daun harus segera dikendalikan dengan menggunakan insektisida kimia yang direkomendasikan agar populasi secara cepat berada dibawah ambang kendali. Moekasan et al. (2004) dan Moekasan \& Prabaningrum (2012), menyebutkan bahwa ambang kendali kutu daun pada tanaman cabai adalah 0,7 ekor per daun pucuk. Setelah satu minggu aplikasi insektisida pertama (pada 3 MST), rata-rata populasi kutu daun yang berada dibawah ambang kendali adalah pada perlakuan Biochar sekam padi +Trichokompos dan Biochar tongkol jagung + Trichokompos. Populasi kutu daun pada perlakuan Biochar ampas tebu + Trichokompos, Trichokompos, dan kontrol menunjukkan masih diatas ambang kendali. Kondisi ini masih diperlukan pengendalian dengan insektisida kimia yang direkomendasikan (Gambar 2).

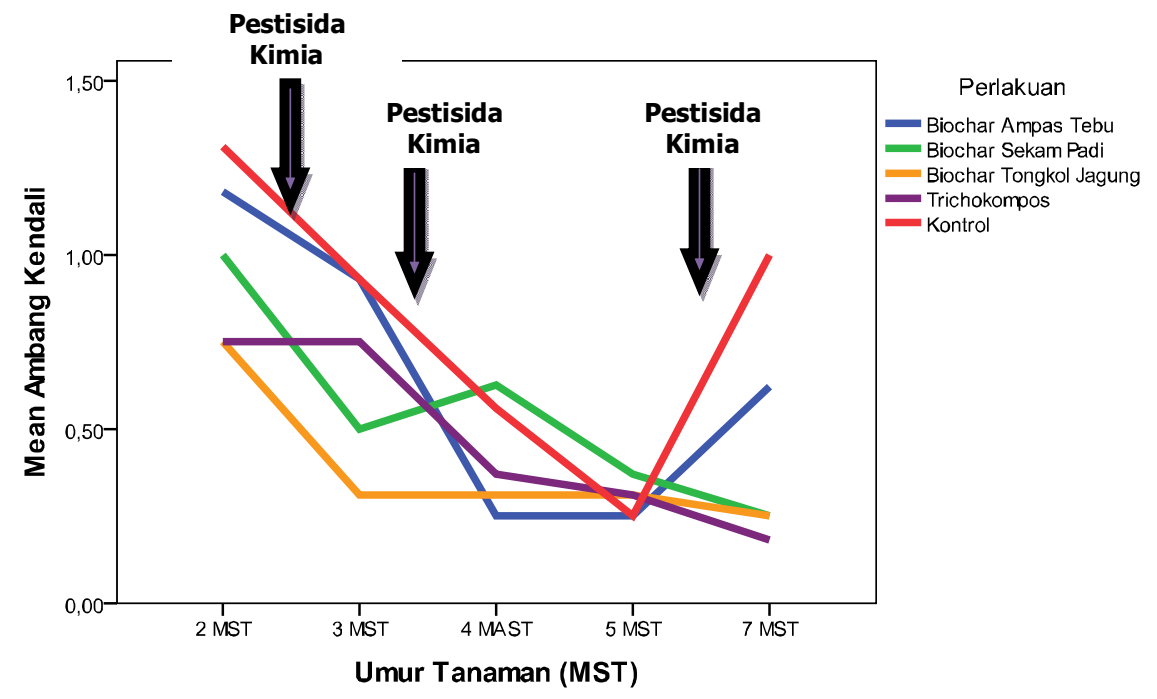

Gambar 1. Nilai ambang kendali populasi kutu daun pada tananaman cabai pada beberapa perlakuan bochar dan trichokompos umur 2-7 MST (Minggu Setelah Tanam)

Diterbitkan oleh Program Studi Agroteknologi Fakultas Pertanian Universitas Batanghari Jambi Halaman 21 
Jurnal Media Pertanian Vol. 3 No. 1 Tahun 2018 Hal. 16 - 23

Media Komunikasi Hasil Penelitian dan Review Literatur Bidang Ilmu Agronomi ISSN print $2503-1279$

ISSN online $2581-1606$

Pada 4 dan 5 MST, populasi kutu daun sudah berada dibawah ambang kendali dan tidak dilakukan pengendalian secara kimia. Selanjutnya pada 7 MST, populasi kutu daun pada kontrol melewati ambang kendali dan aplikasi pengendalian hanya perlu dilakukan pada perlakuan kontrol. Berdasarkan hasil pengamatan dan perkembangan populasi kutu daun pada 2-7 MST dan ambang kendali kutu daun, maka frekuensi pengendalian kutu daun secara kimia dapat dikurangi sampai $50 \%$ dari pengendalian secara berjadwal tiap minggu. Hasil penelitian ini lebih rendah dibanding budidaya cabai varietas Kencana yang ditanam secara monokultur, penggunaan mulsa plastik hitam perak, pemupukan (pupuk kandang sebesar $30 \mathrm{t}$ per ha dan NPK sebanyak $700 \mathrm{~kg}$ per ha), dan penggunaan pestisida berdasarkan ambang kendali, dapat menekan penggunaan pestisida sebesar 73,33\% dengan hasil panen tetap tinggi yaitu sebesar 15,46 t per ha. (Setiawati et al, 2013). Menurut Untung (1994) penggunaan pestisida tidak harus dilakukan setiap saat secara rutin atau terjadwal, tetapi hanya pada waktu tertentu yaitu pada saat populasi atau intensitas serangan OPT mencapai batas yang memerlukan pengendalian dengan cara yang disebut ambang pengendalian. Jika pada saat itu tidak dilakukan pengendalian, serangan OPT dapat mengakibatkan kerugian. Selama populasi atau intensitas serangan OPT masih berada di bawah ambang pengendalian, pestisida belum perlu digunakan. Pada keadaan demikian keberadaan OPT masih dapat dikendalikan secara alami oleh musuh alaminya dan secara ekonomi belum merugikan.

\section{KESIMPULAN}

Penggunaan biochar limbah pertanian (sekam padi, tongkol jagung, ampas tebu) dan trichokompos berpengaruh nyata terhadap tinggi tanaman cabai sampai 7 MST, tetapi tidak berpengaruh nyata terhadap jumlah atau populasi kutu daun.

Pengendalian kimia kutu daun pada tanaman cabai varietas Kencana pada fase vegetatif yang dilakukan berdasarkan ambang kendali, dapat menurunkan frekuensi aplikasi insektisida sampai $50 \%$.

\section{UCAPAN TERIMAKASIH}

Terimakasih kepada Badan Litbang Pertanian atas dukungan dana penelitian. Ucapan terimakasih disampaikan kepada Bapak Alpian Nadi yang sudah meminjamkan lahannya untuk penanaman cabai, kepada Bapak Dedi Mirawan dan Ibu Unah atas pengumpulan data penelitian serta kepada semua pihak yang terlibat dalam penelitian ini..

\section{DAFTAR PUSTAKA}

BPS. 2015. Jambi Dalam Angka 2015. Biro Pusat Statistik, Provinsi Jambi.

Duriat, AS. 2008. Pengaruh ekstrak bahan nabati dalam menginduksi ketahanan tanaman cabai terhadap vektor dan penyakit virus kuning keriting. J. Hort. 18 (4) : 446-456.

Endrizal, A Meilin, Adri, NI Minsyah, Suharyon. 2014. Analisis Kebijakan Pembangunan Pertanian di Provinsi Jambi. Laporan Akhir BPTP Jambi.

Moekasan, TK, E Suryaningsih, I. Sulastrini, N. Gunadi, W. Adiyoga, A. Hendra, M.A. Martono, \& Karsum. 2004. Kelayakan teknis dan ekonomis

Diterbitkan oleh Program Studi Agroteknologi Fakultas Pertanian Universitas Batanghari Jambi Halaman 22 
Jurnal Media Pertanian Vol. 3 No. 1 Tahun 2018 Hal. 16 - 23

Media Komunikasi Hasil Penelitian dan Review Literatur Bidang Ilmu Agronomi

ISSN print $2503-1279$ ISSN online $2581-1606$

penerapan teknologi pengendalian hama terpadu pada sistem tanam tumpanggilir bawang merah dan cabai. J. Hort., 14 (3): 188-203.

Novizan.2007. Petunjuk Pemupukan yang Efektif. Agromedia Pustaka. Jakarta.

Gani, A., 2009. Biochar Penyelamat Lingkungan. Warta Penelitian dan Pengembangan Pertanian. Vol. 31, No. 6.

Gardner FP, Pearce RB, and Mitchell RL. 1991. Physiology of Crop Plants.Diterjemahkan oleh H.Susilo. Jakarta. Universitas Indonesia Press.

Gunaeni, N \& Wulandari AW. 2010. Cara pengendalian non kimiawi terhadap serangga vektor kutudaun dan intensitas serangan penyakit virus mosaik pada tanaman cabai merah. J. Hort., 20 (4): 368-76.

Hou, X, L. Meng, L. Li, G. Pan \& B. Li. 2015. Biochar amendment to soils impairs developmental and reproductive performances of a major rice pest Nilaparvata lugens (Homopera: Delphacidae). J. Appl. Entomol.. doi: 10.1111/jen.12218

Prabaningrum, L dan Moekasan, TK. 2014. Pengelolaan Organisme Pengganggu Tumbuhan Utama Pada Budidaya Cabai Merah di Dataran Tinggi (Pest and Disease Management On Hot Pepper Cultivation in High Land). J.Hort. 24 (2) : 179-188.

Roziq F, IR Sastrahidayat, S Djauhari. 2013. Kejadian Hama Dan Penyakit Tanaman Cabai Kecil Yang Dibudidayakan Secara Vertikultur Di Sidoarjo. Jurnal HPT 1 (4) : 30-36

Schmidt MWI, Skjemstad JO, Czimezik JI, Glaser B, Prentice KM, Gelinas Y, Khulbusch TAJ. 2001. Comparative analysis of black carbon in Soil. Global Biogeochemical Cycle 15: 163-167.

Setiawati, W, Udiarto, BK \& Soetiarso TA. 2007. Selektivitas beberapa insektisida terhadap hama kutu kebul (Bemisia tabaci Genn.) dan predator Menochilus sexmaculatus Fabr. J. Hort. 17(2) : 168-74.

Setiawati, W, Murtiningsih, R \& Hasyim, A. 2011. Laboratory and field evaluation of essensial oil from Cymbopogon nardus as oviposition detterent and ovicidal activities. Indonesian J. Agric. Sci. 12 (1) : 9-16.

Setiawati, W, Sumarni, N, Koesandriani, Y, Hasyim, A, Uhan, TS, dan Sutarya, R. 2013. Penerapan Teknologi Pengendalian Hama Terpadu pada Tanaman Cabai Merah untuk Mitigasi Dampak Perubahan Iklim (Implementation of Integrated Pest Management for Mitigation of Climate Change on Chili Peppers) J. Hort. 23 (2) : 174-183.

Herwidyarti, KH., S.Ratih \& D.R.J Sembodo. 2013. Keparahan Penyakit Antraknosa Pada

Cabai ( Capsicum annuum L) Dan Berbagai Jenis Gulma. J. Agrotek Tropika. 1 (1) : 102 - 106,

Untung, K 1994, 'Konsep, strategi, dan taktik pengendalian hama terpadu dalam menunjang pembangunan pertanian berkelanjutan', Prosiding lokakarya pengembangan entomologi di kawasan timur Indonesia dalam upaya menunjang pengendalian hama terpadu, Faperta Universitas Samratulangi, Manado PHT-BAPPENAS, hlm. 1-20

Diterbitkan oleh Program Studi Agroteknologi Fakultas Pertanian Universitas Batanghari Jambi Halaman 23 